\title{
バレル研磨技術
}

\author{
山本章 裕* \\ *兵庫県立工業技術センター 機械金属工業技術支援センター (
}

\section{Barrel Finishing}

\author{
Akihiro YAMAMOTO*
}

*Technical Support Center-for Machinery and Metals, Hyogo Prefectural Institute of Industrial Research (240-1, Fuke, Hirata-aza, Miki-shi, Hyogo 673-0405)

Keywords : Barrel Finishing, Mass Finishing, Media, Compound

\section{1.はじめに}

バレル研磨の専門書は現在ではほとんどないが，1959 年に 「バレル仕上法」という本が松永の編集により出版されている1)。 ちなみに, 松永は遠心バレル研磨法を力学的に解明する2)な ど, 当時のバレル研磨技術の研究と普及・発展を先導してき た，バレル研磨を語る上で欠かせない人物の一人である。

そして，その本の序抢よび第 1 章には 1954 年と 1955 年の 文部省科学研究総合研究班 (今でいう産官学のプロジェクト チーム)によってバレル仕上の基礎が作られたこと，1956 年 に金属表面技術協会 (現, 表面技術協会) 内にバレル仕上研究 会やバレル委員会が設けられ, 研究の推進と技術の普及が図 られたこと, またバレル委員会では従来のガラ研磨とは内容 も言葉の上でも異なるということで，「Barrel finishing」を 直訳した「バレル仕上」という名称が採用されたことが述べ られており, バレル研磨の黎明期に表面技術協会がいかに大 きな役割を果たしたかということがよくわかる。

バレル研磨は, その名のとおり, バレル(Barrel, 樽) 状 の容器にメディア (Media, 研磨石のようなもの) と工作物を 入れて研磨したことに由来すると考えられ, 現在のような方 法で実施されるようになったのは，米国で第二次世界大戦中 に発達した回転バレル研磨法が, 戦後日本に導入されてから である゙๋。

それまでは, 同様な加工法としてガラ研磨(タンブリング, Tumbling)があったが，これは容器に工作物だけを入れて 回転させ，工作物を容器内で転げ回らせる(Tumble)ことに より工作物が相互に接触し加工されるというものであり, 精 度の要求される部品には使用できなかった。すなわち, バレ ル研磨はメディア等の導入と加工精度の点においてガラ研磨 とは大いに異なっており, 精密部品の大量仕上げはバレル研 磨によって初めて可能になったといえる。

バレル研磨と用途が重なる加工法に, バフ研磨, ベルト研 削, ブラシ加工などがある。これらは, 機械製品や部品の製 造における仕上工程でバリ取りおよびエッジの面取りや丸味
付けあるいは表面粗さの改善や光沢付与による装飾性の向上 に使用される代表的な加工法であるが，手作業で行われるこ とが多く, 品質の安定において問題がある。一方, バレル研 磨は, 研磨条件の選定によって, これらの加工法のいずれに も匹敵するような仕上げが可能であり，しかも多数のものを 同時に均一に仕上げることができるという特徵をもっている。 そのため, 特に手作業による仕上工程の合理化や精密部品の 大量仕上げにはバレル研磨が利用されることが多く, バレル 研磨機が設置されている工場も少なくない。

しかし, バレル研磨においては, バレル研磨方式や加工条 件の選定が研磨結果に大きな影響を与えるので, 非常に多く の選択肢の中から目的の研磨結果を得られる条件を選定する のは容易ではない。

そこで, バレル研磨技術の導入や研磨条件選定の参考とな るようバレル研磨技術の基礎について解説する。

\section{2. バレル研磨法の種類 ${ }^{4)}$}

バレル研磨とは, バレル(容器, 槽)の中に工作物, メディ ア, 水抢よびコンパウンド (Compound, 研磨を助ける洗剤 のようなもの)を装入して, バレル，工作物もしくはメディ アに運動を与えることにより, 工作物とメディアの間に相対 運動を生じさせて, その摩擦作用により研磨する方法であり, その運動の与え方や組合わせによって, 多くの方式が考えら れている。また，バレル内面にはゴムなどのライニングを施 し，工作物との接触によるお互いの損傷を防止している。 とくに，バレル研磨はほとんどの場合バッチ処理であり, 不適切な条件で研磨すると, 不良品が大量に発生するので, 研磨条件の選定は, 予備実験を実施するなど, 慎重に行う必 要がある。

\section{1 回転バレル研磨法}

回転バレル研磨法は, 図 1 のように容器に回転運動を与え てマス(工作物十メディア)の表層部に滑りを発生させる(マ スを流動させる)ことにより，工作物とメディアの間に相対 運動を生じさせて, 研磨する方法である。回転バレル研磨法 
においては，このマスの表層部の流動層で研磨されるので， この流動層の深さと長さが大きいほど研磨性能が良い。すな わち，マスの表層部の長さは，マスの体積がバレル容積の $50 \%$ ときに最大となるので，一般にバレル容積の 50〜60\%の装入量で研磨される。

回転バレル研磨機には，バレルを密閉して水平に設置する ものと,バレルを傾斜して設置することによりバレルの一部 に開口部を設けたものがある。

\section{2 振動バレル研磨法}

振動バレル研磨法は, 図 2 のように研磨槽に振動を与える ことにより，マスを流動させて研磨する方法である。研磨槽 の振動は, 槽をバネで支持し, 槽に取り付けられた偏心軸工 ニットや振動モータ (モー夕軸両端に偏心重りがついている) により発生させる。

振動バレル研磨法においては，マス全体で研磨されるので, 研磨能率は回転バレル研磨法の $3 \sim 5$ 倍といわれている。ま た, 研磨槽へのマスの装入量は, 研磨槽容積の $80 \%$ 程度で あり，1回当たりの工作物の処理量も多い。また，振動バレ ル研磨機には, 研磨槽の形状によりサークル型とボックス型 がある。

\section{3 遠心バレル研磨法}

遠心バレル研磨法は, 図 3 のようにバレルをタレットと呼 ばれる回転円盤に偏心させて取付け, タレットの回転に比例 して自転させることにより，バレル内のマスの表層を遠心力 によってバレルの回転方向に流動させて研磨する方法である。 タレットとバレルの回転数の比を適当にしさえすれば，マス がバレル内壁に固着することはないので，バレル回転速度の 高速化により，研磨能率をいくらでも高くすることができる。

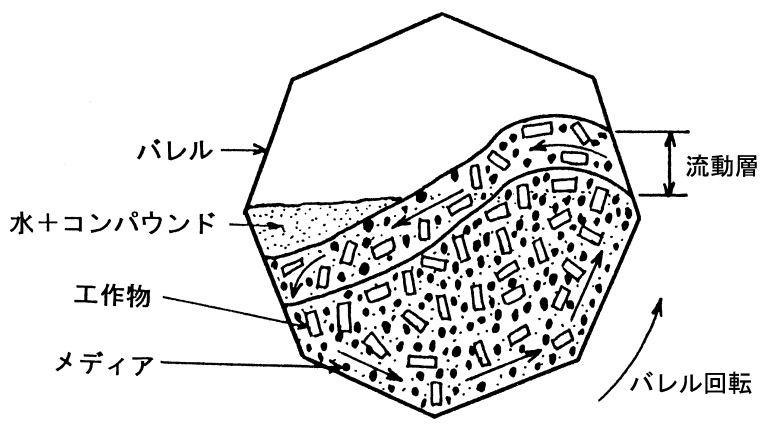

図 1 回転バレル研磨法におけるマスの流動
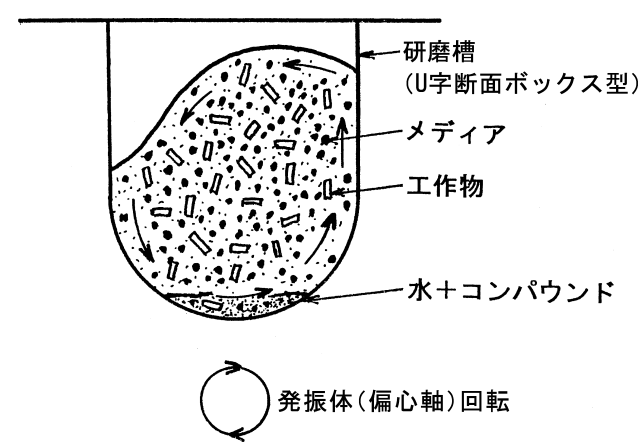

図 2 振動バレル研磨法におけるマスの流動(ボックス型)
しかし, 現実には装置やメディアの強度に限界があるので, その研磨能率は回転バレル研磨法の数十倍である。また, 研 磨能率が高いので, 研磨時間が短くてすみ, 小さな部品の研 磨に効果を発揮する。

\section{4 流動バレル研磨法}

流動バレル研磨法は, 図 4 のように研磨槽の底部だけを回 転することにより，マスをらせん状に流動させて研磨する方 法である。すなわち, マスは遠心力で側壁に向かって押し出 され, 側壁に沿って上昇し, 上昇してくるマスの上を底部の 回転中心に向かって滑り落ち, 再び遠心力により側壁の方向 に押し出されるというらせん状運動を繰り返す。また, 研磨 槽へのマスの装入量は研磨槽容積の $60 \%$ 程度であり, 研磨能 率は遠心バレル研磨法と振動バレル研磨法の中間に位置する。

\section{5 その他のバレル研磨法}

その他のバレル研磨法として，ジャイロ研磨法とレシプロ 研磨法がある。ジャイロ研磨法は, 軸に取付けられた工作物 をメディア，水拉よびコンパウンドの入った研磨槽に挿入し， 研磨槽と軸を同時に回転させ研磨する方法である。また，レ シプロ研磨法は, メディア，水抒よびコンパウンドの入った 研磨槽に取付用ジグに固定した工作物を挿入し, 往復運動を 与えることによって研磨する方法である。

実際のバレル研磨においては，さらに多くの方法が行われ ているが，これまで述べてきた工作物とメディアの運動方向 を変えたり, 組み合わせたりしたものであり, 基本的には以 上に述べたいずれかに分類される。また, 現在ではバレル研 磨方式が増え，バレル状の容器を使用しないものが多くある ので，米国ではバレル研磨全体を指す場合には，「Barrel

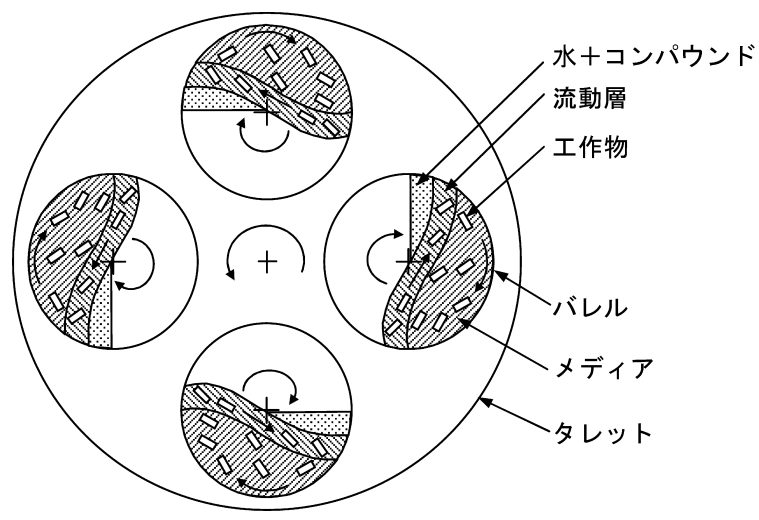

図３＼cjkstart遠心バレル研磨法におけるマスの流動

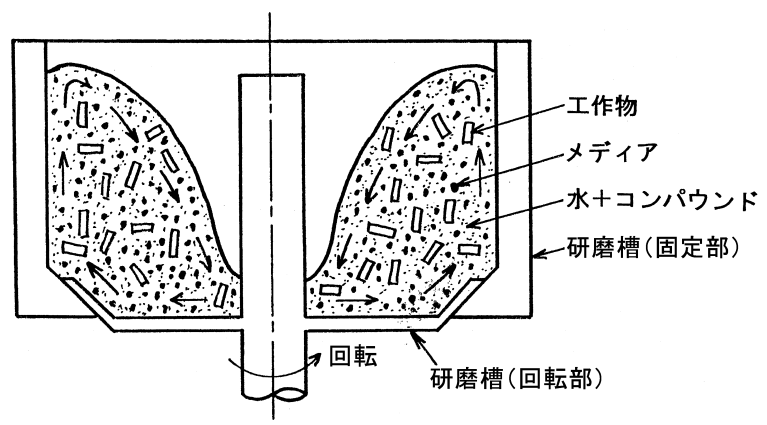

図4＼cjkstart流動バレル研磨法におけるマスの流動 
finishing」よりも「Mass finishing」の方がよく使われるよ うである。

研磨能率に関しては，全く同一の研磨条件で研磨すること は不可能であるので箃密な比較はできないが，傾向としては 回転, 振動, 流動, ジャイロ, 遠心の順に高くなる。

\section{3. 研磨条件 5 ),6)}

バレル研磨条件としては，メディア，コンパウンド，マス の装入量, 工作物とメディアの混合比などが挙げられ，その 選定が研磨結果に重要な影響を与える。

\section{1 メディア}

基本的には, 工作物材質と研磨目的によって, メディア材 質が選定され，工作物のどの部分にもメディアが接触できる ように工作物形状と寸法によって，メディア形状と寸法が選 定される。図 5 は, 代表的なメディア材質と形状を示したも のである。

昔は, バレル研磨用メディアとして, 天然産の不定形研磨 石(花崗岩, 石灰石, 大理石, ケイ石, 砂など)が使用されて いたが，最近では人造砥粒を適当な結合剤によって成形した メディアが使用されている。そこで，代表的なメディアとそ の用途について説明する。

セラミックスメディアは, その成形方法によって焼成メ ディアと焼結メディアに分けられる。しかし，セラミックス メディアといえば，一般に焼成メディアを指すことが多く, 焼結メディアは微小切削研磨石もしくは微小切削用メディア として分類されることもある。

焼成メディアは, アルミナ砥粒 $\left(\mathrm{Al}_{2} \mathrm{O}_{3}\right)$ をビトリファイド 結合剂により，加熱・成形したもので，球状，三角柱状ある いは円柱状などの多くの形状・寸法のものがある。また，焼 成メディアは研磨作用に優れ, 寿命が長く, 工作物に大きな 擦過痕をつけないなどの特徵があり, スケール取り, バリ取 りなどの粗仕上げからメッキの下地処理などの細仕上げまで 広範囲に使用される。

焼結メディアは, アルミナの微粉末 (数 $\mu \mathrm{m}$ ) を高温で焼結 させたものである。すなわち, 焼結メディアの場合, 微小な 砥粒が微小なピッチで並んでいると考えられるので, 良好な 仕上面が得られ, しかも個々の砥粒の研磨量は少ないが, 作

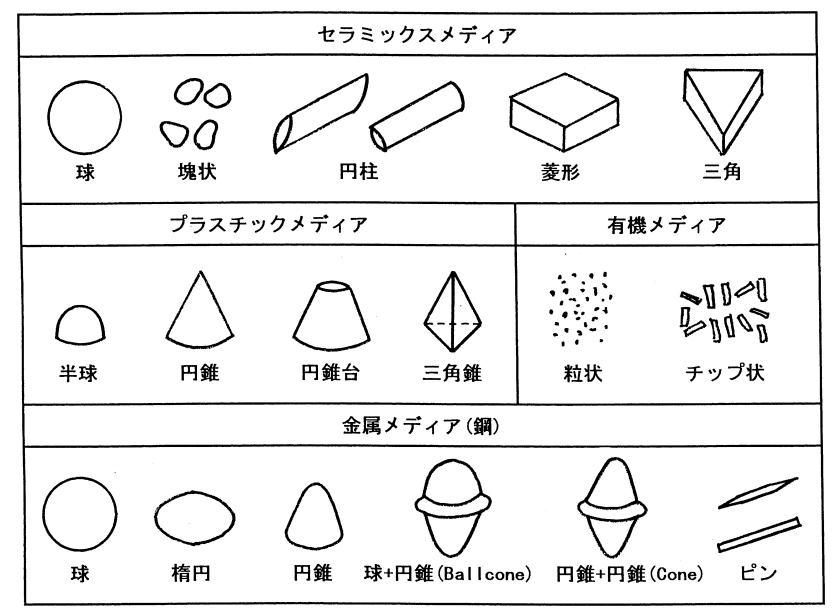

図 5 代表的なメディアの形状
用砥粒数は多いので, 小さなメディアでも比較的大きな研磨 量が得られるという特徵がある。そのため, 研磨量と仕上面 粗さを同時に要求される工程において使用される。

金属メディアは，その硬さによって使用目的が異なる。す なわち，工作物より硬い金属メディアは，バニッシングによ る光沢仕上げに利用される。メディアとしては，スチール ボールが最も多く, アルミニウム合金, ステンレス鋼, 銅合 金などに使用される。工作物より軟らかい亜鉛や銅などの金 属メディアは, 微粉研磨材を含んだコンパウンドと一緒に研 磨仕上げに利用される。この場合の金属メディアは研磨材を 保持し，研磨作用力を向上させるためのものである。

有機質メディアは, 竹, くるみの凯, 木片, とうもろこし の穂軸 (corncob) などを適当な寸法に成形または粉砕し, 油 脂を付けて，アルミナや酸化クロムなどの研磨材をコーティ ングしたもので, 天然メディアに属し, 主に合成樹脂(ボ夕 ン, ツマミなどの装飾部品や眼鏡枠など) の光沢仕上げに使 用される。また, 有機メディアは, 他のメディアと異なり水 に浮いたり, 水で柔らかくなったりするので, 乾式研磨用で あり，水と一緒に使用しない。

プラスチックメディアは, 合成樹脂を結合剤として砥粒を 成形したものであり, 非鉄合金, 特に悪鉛, アルミニウム合 金のような軟質金属の仕上げに利用される。比重が小さいの で工作物に加工硬化を生じることもほとんどなく, 研磨中の 騒音や振動も比較的少ない。また, 目詰まりや破砕がなく化 学的に安定しているという特徵がある。

すなわち，スケール取りやバリ取りなどの粗〜中仕上げの 場合には焼成メディアが選定され，細〜光沢仕上げの場合に は焼結メディアや金属メディアが選定される。

また，たとえば工作物に穴がある場合，穴の中に入って研 磨ができ, しかも穴に詰まらない(穴より少し小さいか穴径 の 1 / 3 以下の)大きさの球状メディアなどが選定される。

\section{2 コンパウンド}

コンパウンドは, 工作物材質と研磨目的によって選定され, 酸性, アルカリ性および中性に大別されるが, メーカも種類 も多いので，その説明書に従って使用するのが基本である。

酸性コンパウンドは, 腐食性が強く錆の発生原因にもなる ので, 熱処理によるスケールや錆の除去以外にはほとんど使 用されない。とくに, 研磨後はアルカリ性溶液で中和し, 水 洗する必要がある。

アルカリ性コンパウンドは, 最も利用範囲が広く, 錆や変 色を防ぎ, 酸性コンパウンドの中和剤にもなるばかりでなく, 最終仕上げの前の脱脂や洗浄剤としても使用される。

中性コンパウンドは, 最終仕上げに使用され, 工作物とメ ディアの間の緩衝および潤滑を行う。

すなわち, スケール取りには酸性, 光沢仕上げには中性, それ以外にはアルカリ性コンパウンドを使用し，その量はコ ンパウンドの種類やメーカによって異なるが, 概水水 $1 \mathrm{dm}^{3}$ につき $20 \mathrm{~g}$ 程度である。

\section{3 その他}

マスの装入量は, 研磨槽の容積に対して回転および遠心バ レル研磨法では 50\%, 振動バレル研磨法では $80 \%$, 流動バ レル研磨法では $60 \%$ 目安とし調整する。たとえば，流動 
バレル研磨機においては, 回転速度が最大のとき槽から溢れ 出ないことが条件であるので，回転速度を低下させれば，マ スの装入量を増加させることは可能である。

水の量は, 回転, 遠心および流動バレル研磨法では, 研磨 槽におけるその水位をマスの表面に一致させる。また，振動 バレル研磨法では，マスが需れる程度でよく，マスの体積の $5 \%$ 程度である。そして, これらの水の量からコンパウンド の量を算出する。

工作物とメディアの混合比は, $1: 3 \sim 1: 6$ (工作物体 積：メディア体積)の間で選定されることが多く, メディア 体積の多い方が工作物同士による打痕の発生が少なく, きれ いに仕上がる。

すなわち, 研磨条件の選定とは, 研磨目的と工作物の材 質・寸法・形状から適当な研磨条件を選定して実験を行い, 表 1 に示す研磨条件の変化が仕上げに及ぼす影響の傾向を参 考にして研磨条件を修正し研磨目的が達成できるようにする ことである。

研磨量や表面粗さは, バレル研磨機の容器を駆動するモー 夕回転数によって変化させることはできるが, メディアを変 更するほどには変化しないので, 研磨条件の選定においては, 一般に研磨目的に合致した研磨結果が得られるようメディア とコンパウンドを選定し, 他の条件は固定することが多い。

\section{4. バレル研磨面の特徵}

バレル研磨法が，歯車やバネの寿命改善に有効であること は経験的に知られている。これは, バレル研磨による歯車や バネの表面性状の変化に起因するものと考えられるので，バ レル研磨前後の表面性状の変化について説明する。

図 6 は, 浸炭窒化処理を施した高炭素クロム軸受鋼のピン を表面粗さの值がバレル研磨前後でほぼ同じになったときの 表面形状を示したものである。研磨前には旋削加工の周期的 な送りマークが明確に現れていたが，バレル研磨後には送り マークは消え, 山の間隔が狭まりち密な表面になっている。 このことは, 摩擦部における一山当たりの作用力の減少にな るので, 耐摩耗性の向上につながると考えられる。

図 7 は, 表面から $0.1 \mathrm{~mm}$ 入ったところの断面の硬さを示 したものである。研磨後の方が表面付近において, 硬さが高

表 1 仕上げへの影響因子

\begin{tabular}{|c|c|c|c|c|}
\hline & 要＼cjkstart因 & 粗仕上げ & & 細仕上げ \\
\hline 原因 & $\begin{array}{l}\text { 工作物とメディアの } \\
\text { 接触圧(研磨力) }\end{array}$ & 高 & & 低 \\
\hline 結果 & $\begin{array}{l}\text { 研磨量 } \\
\text { 仕上面粗さ } \\
\text { 工作物のひずみ }\end{array}$ & $\begin{array}{l}\text { 大 } \\
\text { 大 } \\
\text { 大 }\end{array}$ & & $\begin{array}{l}\text { 小 } \\
\text { 小 } \\
\text { 小 }\end{array}$ \\
\hline $\begin{array}{l}\text { 加工 } \\
\text { 条件 }\end{array}$ & $\begin{array}{l}\text { 砥粒・メディア寸法 } \\
\text { メディアの形状 } \\
\text { 水の量 } \\
\text { メディアの量 } \\
\text { 工作物の量 } \\
\text { 工作物とメディアの } \\
\text { 混合比 } \\
\text { 装置回転数(振動数) } \\
\text { コンパウンド }\end{array}$ & $\begin{array}{c}\text { 大 } \\
\text { 菱形, 三角柱 } \\
\text { 少 } \\
\text { 少 } \\
\text { 多 } \\
\text { 大 } \\
\text { 高 } \\
\text { 酸性 }\end{array}$ & 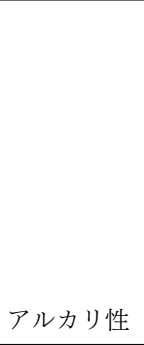 & $\begin{array}{l}\text { 小 } \\
\text { 球 } \\
\text { 多 } \\
\text { 多 } \\
\text { 少 } \\
\text { 小 } \\
\text { 低 } \\
\text { 中性 }\end{array}$ \\
\hline
\end{tabular}

いのは, バレル研磨による表面の加工硬化に起因するものと 考えられる。また, 研磨後に硬さの増大が認められることか ら，バレル研磨により耐摩耗性が向上することがわかる。

図 8 は, 表面の残留応力を示したものである。いずれの残 留応力も圧縮 (マイナス) で, 研磨後は研磨前の約 4 倍に増大 している。圧縮の残留応力は疲労寿命を改善することから， バレル研磨によって疲労寿命が向上することが期待できる。

このほかに，メディアが工作物と接触することにより，工 作物表面に極微細な砥粒の埋込みが発生する7)。これの影響 はほとんど無く, 一般に無視されているが, 微小領域の表面 特性が問題となる場合には考慮する必要がある。

\section{5. 最新の動向}

バレル研磨装置の改良や自動化はこれまでずっと行われて
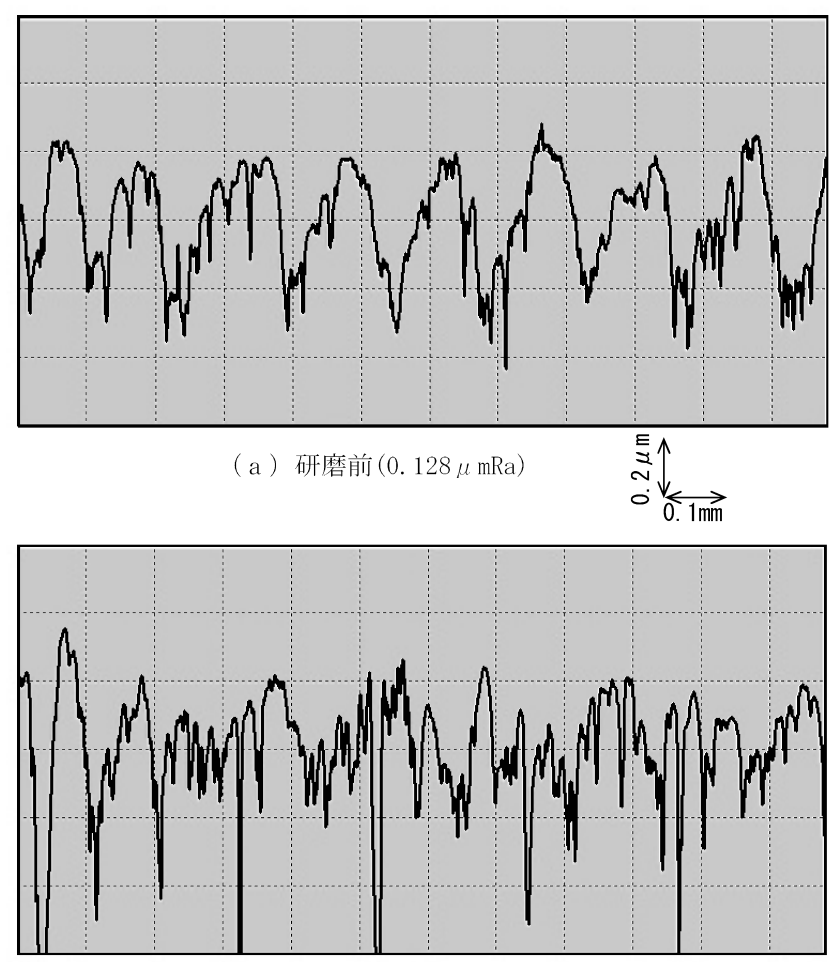

（b ）研磨後 $(0.124 \mu \mathrm{mRa})$

図 6 バレル研磨による表面粗さの変化 遠心バレルによりメディアVRT $10 \times 7$ と FMB 3 で各 1 時間研磨

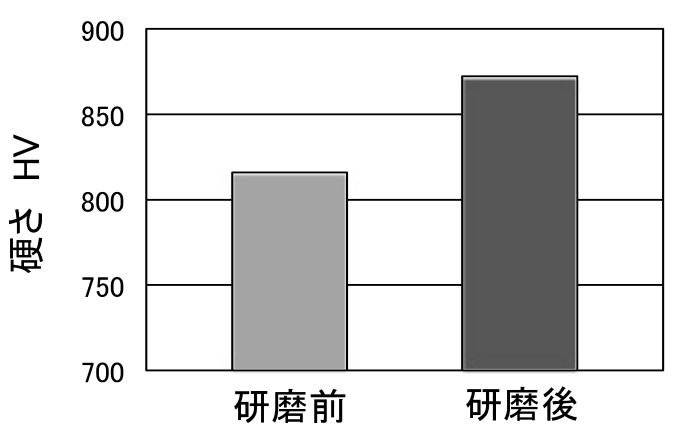

図 7 バレル研磨による表面の硬さの変化 遠心バレルによりメディアVRT $10 \times 7$ と FMB 3 で各 1 時間研磨 


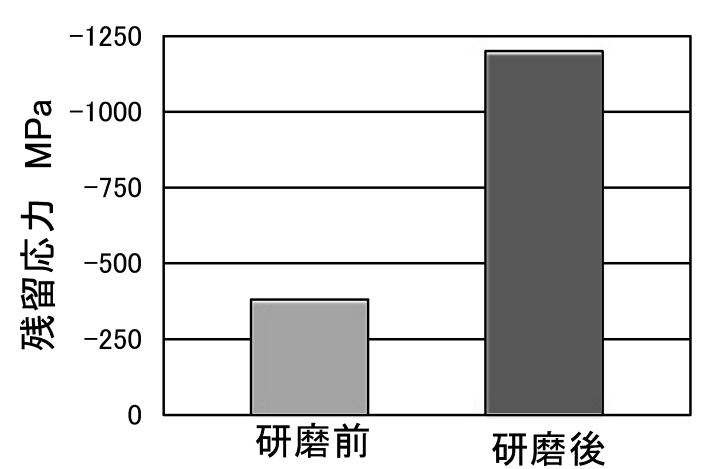

図 8 バレル研磨による表面の残留応力の変化 遠心バレルによりメディアVRT $10 \times 7$ と FMB 3 で各 1 時間研磨，X 線回折応力測定法により測定

きており，バレル研磨の無人化モデル工場まで既に完成して いる現状においては，目新しいものはほとんどない8)。

しかし, 最近の傾向として, 環境が重要視されるので, 適 正な廃水処理をしていても, 工場から排水することがはばか られるようになってきている。そのため, 焼成メディアと同 等の研磨が乾式でも行えるというメディアが普及してきてい る9)。この乾式研磨用メディアは, 水を使用しないという点 において, 前述のプラスチックメディアと全く異なるだけで なく, 耐摩耗性や耐熱性に優れたナイロンなどの高分子材料 に砥粒を混合して成形することによりメディア自身に緩衝作 用を持たせて, 一般鋼材部品の粗仕上げから細仕上げまでの 広範囲の研磨が乾式で行えるという点において, 有機メディ アとも異なっている。

また, プラスチック容器 (非磁性体) にメディア(磁性体), 工作物 (非磁性体)，水およびコンパウンドを装入し，プラス チック容器底部から磁力を回転させながら作用させることに より，メディアを回転させ，磁力の影響を受けない工作物と の間に相対速度を発生させ研磨する方法が開発されている ${ }^{10)}$ この方法は, 磁気バレル研磨法と呼ばれており, マスの流動 方法に磁気を利用したという点において全く新しいものであ るが，バレル研磨法の一種であると考えられ，その利用分野 も指輪などの貴金属の研磨からアルミニウム, 黄銅, セラ ミックス等の機械部品の研磨へと広がっている。

\section{6. おわりに}

バレル研磨技術は, 比較的単純な構造の装置で, バリ取り やエッジ仕上げなどの手作業が自動化できるだけでなく, 粗 仕上げから鏡面仕上げまでの研磨ができる, 非常に用途の広 い加工法である。しかし, 未だに多くの仕上げが手作業で行 われていることや導入されている工場においてもバレル研磨 の専門家が抢らず, 研磨条件の選定も経験と勘で行われてい ることが多いなど, 産業界において十分にその能力が発揮で きる状況を与えられているようには思えない。

また, バレル研磨技術の研究においても, バレル研磨機な どのメーカにほとんど依存しているため, 公表されることが 少なく, バレル研磨に係わる者全体として共有されている知 識はここに述べられている程度のことにすぎない。メーカや 研究者を上流としバレル研磨による実際の仕上げの現場を下 流とすると, 実際の川とは逆に, 下流に行くほどバレル研磨 に関する知識や情報は狭く浅くなっている。

本報が，バレル研磨技術の導入や研磨条件の見直しのきつ かけとなるだけでなく, このような現状の改善や研究発展の 一助となれば幸いである。

(2006-8-15 受理)

\section{文 献}

1 ）松永正久編；バレル仕上法, p. 1（誠文堂新光社, 1959).

2 ) 松永正久; 生産研究, 18, (3), 71 (1966).

3 ）木下直治, 高沢孝哉偏; 表面研磨 - 仕上技術集成, p. 275（日 経技術図書, 1984).

4 ）木下直治, 高沢孝哉偏; 精度設計と部品仕上げシステム技術, p. 502 (日経技術図書, 1989).

5 ）新東ブレーター編；バレル研磨一装置とプロセスー, p. 1 (新 東ブレーター, 1975).

6 ) チップトン編；バレル研磨の手引.

7 ) 北嶋弘一, 山本章裕; 砥粒加工学会誌, 47, 123 (2003).

8 ）小林久峰, 松田 至; 機械技術, 33, (10), 55 (1985).

9 ）石田喬男, 吉田昭一, 河野洋一郎, 平賀幹敏; 新東技報, 14,39 (1994)

10）杉浦 修，三科 修，中山信一; 砥粒加工学会誌，43，273 (1999). 